\title{
PREPRINT- Adsorption behavior of new theophylline-triazole based derivatives as effective corrosion inhibitors for steel in acidic medium
}

\author{
Araceli Espinoza-Vázquez a , Francisco Javier Rodríguez-Gómeza ${ }^{\text {a }}$ Ivonne Karina \\ Martínez-Cruz ${ }^{\mathbf{b}}$, Deyanira Ángeles-Beltrán, ${ }^{\mathrm{b}}$ Guillermo E. Negrón-Silva ${ }^{\mathrm{b} *}$, Manuel \\ Palomar-Pardavé, ${ }^{\mathrm{c}}$ Leticia Lomas Romero, ${ }^{\mathrm{c}}$ Diego Pérez-Martínez ${ }^{\mathrm{c}}$
}

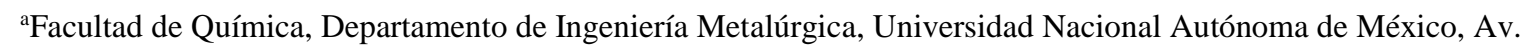
Universidad No. 3000, Coyoacán, C.U., Ciudad de México, C.P. 04510, México.
}

\begin{abstract}
bDepartamento de Ciencias Básicas, Universidad Autónoma Metropolitana-Azcapotzalco, Av. San Pablo No. 180, Ciudad de México, C.P. 02200, México

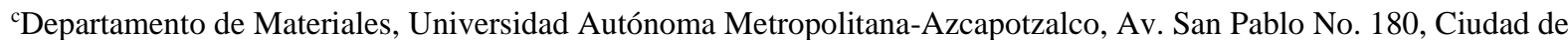
México, C.P. 02200, México. `Departamento de Química, Universidad Autónoma Metropolitana-Iztapalapa, Av. San Rafael Atlixco No. 186, Ciudad de México, C.P. 09340, México.
}

Keywords: inhibitors, API 5L X52, adsorption Preprint doi: 10.31223/osf.io/jvkqr

\section{Summary}

The design and synthesis of a series of theophylline derivatives containing 1,2,3-triazole moieties is presented. The corrosion inhibition activities of these new triazole-theophylline compounds were evaluated by studying the corrosion of API 5L X52 steel in $1 \mathrm{M} \mathrm{HCl}$ media. The results showed that an increase in the concentration of the theophylline-triazole derivatives also increases the charge transference resistance $\left(R_{\mathrm{ct}}\right)$ value, enhancing inhibition efficiency and decreasing the corrosion process. The electrochemical impedance spectroscopy under static conditions studies revealed that the best inhibition efficiencies $(\sim 90 \%)$ at $50 \mathrm{ppm}$ are presented by the all- substituted compounds. According to the Langmuir isotherm, the compounds 4 and 5 analyzed exhibit physisorptionchemisorption process, with exception of the hydrogen 3, bromo 6 and iodo 7 substituted compound, which exhibit chemisorption process. Finally, SEM-EDS analysis of the steel was performed after submerging it in $1 \mathrm{M} \mathrm{HCl}$ in the presence of different concentrations of the organic inhibitor. The corrosion process in the studied material decreases considerably, as expected, by increasing the concentration of the organic inhibitors, reaching a peak in corrosion inhibition at a concentration of $50 \mathrm{ppm}$.

\section{Introduction}

*Author for correspondence (gns@azc.uam.mx).

†Present address: Departamento de Ciencias Básicas, Universidad Autónoma Metropolitana-Azcapotzalco, Av. San Pablo No. 180, Ciudad de México, C.P. 02200, México 


\section{R. Soc. open sci. article template}

Steel corrosion remains as one of the most significant problem to industry. This naturally occurring phenomenon, that takes place at the metal-solution interface, substantially decrease the life of the equipment and facilitates the dissolution of environmentally toxic metal from the components [1-3]. In this regard, several organic molecules are recognized as corrosion inhibitors for several metals and alloys [4-6]. The adsorption of organic molecules at the metal surface both disrupts the properties of the metal/solution interface, effectively inhibiting the corrosion process [7], and eliminates the need for expensive and toxic inhibitor compounds [8].

It has been found that molecules with lone electron pairs and/or $\pi$-electrons in their structure shows great affinity to be adsorpted into the metallic material [9-12]. Thus, heterocycles containing nitrogen, oxygen, sulphur, and unsaturation in its structure are excellent candidates to be evaluated as corrosion inhibitors. In this context, nitrogencontaining heterocycles have been regarded as the most effective corrosion inhibitors of steel in acid solutions [13, 14].

Additionally to their biological activities [15-21], nitrogen-containing heterocycles derived from xanthine, such as caffeine has demonstrated to possess great activity as corrosion inhibitors for a series of metals and alloys, although theophylline and theobromine promote corrosion under certain conditions [22, 23]. Recently, theophylline has been studied as a corrosion inhibitor using an API 5L X70 steel and proved effective at low concentrations [24].

On the other hand, the triazole derivatives are another class of nitrogen-containing heterocycles that have drawn attention for their potential applications in pharmaceutics, coordination chemistry and as corrosion inhibitors. Several reports have highlighted the capabilities of these compounds to strongly absorb on metal surfaces, achieving an adequate corrosion inhibition efficiency at low concentrations [25-32].

A typical pathway to enhance the corrosion inhibition efficiency of a given heterocycle is to modify its structure with various substituents or functional groups. Moreover, a synergistic effect could be achieved if those substituents possess corrosion inhibition activity by themselves. Accordingly, this work presents the design and synthesis of new theophylline derivatives bearing 1,2,3-triazole moieties, which are interesting, low-cost, and easy to prepare compounds. These novel compounds were tested as corrosion inhibition species to establish structure-activity relationships and to gain further insight into their adsorption properties and the steel protection.

\section{Materials and Methods}

\subsection{Synthesis of the theophylline-triazole inhibitors}

\subsubsection{1,3-dimethyl-7-(prop-2-in-1-yl)-3,7-dihydro-1H-purine-2,6-dione (2).}

Compound 2 was synthesized following the procedure described by Ruddarraju et al [21]. A mixture of theophylline (1) $(1.98 \mathrm{~g}, 11 \mathrm{mmol})$ and potassium carbonate $(1.990 \mathrm{~g}, 14.4 \mathrm{mmol})$ in DMF $(30 \mathrm{~mL})$ were stirred vigorously at room temperature for 20 minutes. After this time, propargyl bromide $(1.68 \mathrm{~mL}, 22.2 \mathrm{mmol})$ was added and temperature was increased at $85^{\circ} \mathrm{C}$ with vigorous stirring for another $2 \mathrm{~h}$. Then, the mixture was poured in cold water. The compound was recovered as a white powder: yield $80 \%$, m.p. $220-222{ }^{\circ} \mathrm{C} .{ }^{1} \mathrm{H} \mathrm{NMR}\left(500.13 \mathrm{MHz}, \mathrm{CDCl}_{3}\right): \delta(\mathrm{ppm})=$ $2.60(1 \mathrm{H}, \mathrm{t}, \mathrm{J}=2.61 \mathrm{~Hz}, \mathrm{H} 12), 3.41\left(3 \mathrm{H}, \mathrm{s}, \mathrm{N} 1-\mathrm{CH}_{3}\right), 3.60\left(3 \mathrm{H}, \mathrm{s}, \mathrm{N} 3-\mathrm{CH}_{3}\right), 5.17(2 \mathrm{H}, \mathrm{dd}, \mathrm{J}=2.6,0.62 \mathrm{~Hz}, \mathrm{H} 10), 7.83(1 \mathrm{H}, \mathrm{t}$, $\mathrm{J}=0.53 \mathrm{~Hz}, \mathrm{H} 8) .{ }^{13} \mathrm{C} \mathrm{NMR}\left(125.77 \mathrm{MHz}, \mathrm{CDCl}_{3}\right): \delta=27.96\left(\mathrm{~N} 1-\mathrm{CH}_{3}\right), 29.79\left(\mathrm{~N} 3-\mathrm{CH}_{3}\right), 36.44(\mathrm{C} 10), 75.43$ (C11), 76.07 (C12), 106.71 (C5), 140.42 (C8), 148.92 (C4), 151.60 (C2), 155.23 (C6). FT-IR/ATR vmax/cm-1: 3243.55, 3111.71, 2946.11, 2127.13, 1703.88, 1651.15, 1543.95, 1477.34, 1437.21, 1373.59, 1232.32, 1190.89, 1025.01, 977.45, 744.20.

\subsubsection{7-((1-benzyl-1H-1,2,3-triazol-4-yl) methyl)-1,3-dimethyl-3,7-dihydro-1H-purine-2,6-dione (3).}

A mixture of compound $2(206 \mathrm{mg}, 1 \mathrm{mmol})$, sodium ascorbate $(40 \mathrm{mg}, 0.2 \mathrm{mmol})$, sodium azide (78 mg, $1.2 \mathrm{mmol})$, benzyl chloride $(0.14 \mathrm{~mL}, 1.2 \mathrm{mmol})$, and $\mathrm{Cu} / \mathrm{Al}$ mixed oxide $(40 \mathrm{mg})$ in $6 \mathrm{~mL}$ of ethanol/water (3:1) were stirred at $80{ }^{\circ} \mathrm{C}$ for $30 \mathrm{~min}$ with microwave radiation. After this time, the $\mathrm{Cu} / \mathrm{Al}$ mixed oxide is recovered by centrifugation and the supernatant is poured in $20 \mathrm{~mL}$ of water, extracted with dichloromethane, and dried over sodium sulfate 
anhydrous. Compound 3 is obtained, after chromatographic purification $\left(\mathrm{CH}_{2} \mathrm{Cl}_{2}: \mathrm{EtOH} 95: 5\right)$, as a white powder: yield 78\%, m.p. $169-171{ }^{\circ} \mathrm{C} .{ }^{1} \mathrm{H}$ NMR $\left(500.13 \mathrm{MHz}, \mathrm{CDCl}_{3}\right): \delta=3.38\left(3 \mathrm{H}, \mathrm{s}, \mathrm{N} 1-\mathrm{CH}_{3}\right), 3.56\left(3 \mathrm{H}, \mathrm{s}, \mathrm{N} 3-\mathrm{CH}_{3}\right), 5.49(2 \mathrm{H}, \mathrm{s}$, H13), 5.56 (2H, s, H10), 7.26 (2H, m, H15), 7.36 (3H, m, H17, H16), 7.75 (1H, s, H12), 7.81 (1H, s, H8). ${ }^{13} \mathrm{C}$ NMR (125.77 $\left.\mathrm{MHz}, \mathrm{CDCl}_{3}\right): \delta=27.98\left(\mathrm{~N} 1-\mathrm{CH}_{3}\right), 29.81\left(\mathrm{~N} 3-\mathrm{CH}_{3}\right), 41.48$ (C10), 54.32 (C13), 106.45 (C5), 123.48 (C12), 128.09 (C15), 128.89 (C17), 129.15 (C16), 134.23 (C14), 141.32 (C8), 142.52 (C11), 148.93 (C4), 151.58 (C2), 155.40 (C6). FT-IR/ATR vmax/cm-1: 3114.70, 2957.28, 1690.39, 1650.26, 1546.81, 1453.58, 1214.63, 1021.75, 749.91. HRMS (ESI-TOF) (calculated for $\left.\mathrm{C}_{17} \mathrm{H}_{18} \mathrm{~N}_{7} \mathrm{O}_{2}+\mathrm{H}+\right)$ : 352.1516; found: 352.1514 .

3.1.3. 7-((1-(4-fluorobenzyl)-1H-1,2,3-triazol-4-yl) methyl)-1,3-dimethyl-3,7-dihydro-1H-purine-2,6-dione (4).

Compound 4 was synthesized following the procedure described previously for compound 3 , from compound 2 and 4-fluorobenzyl chloride. Compound 4 is obtained, after chromatographic purification $\left(\mathrm{CH}_{2} \mathrm{Cl}_{2}: \mathrm{EtOH} 95: 5\right)$, as a white powder: yield $90 \%$, m.p. $184-186{ }^{\circ} \mathrm{C} .{ }^{1} \mathrm{H}$ NMR $\left(400.13 \mathrm{MHz}, \mathrm{CDCl}_{3}\right): \delta=3.39\left(3 \mathrm{H}, \mathrm{s}, \mathrm{N} 1-\mathrm{CH}_{3}\right), 3.56\left(3 \mathrm{H}, \mathrm{s}, \mathrm{N} 3-\mathrm{CH}_{3}\right)$, $5.47(2 \mathrm{H}, \mathrm{s}, \mathrm{H} 13), 5.56(2 \mathrm{H}, \mathrm{s}, \mathrm{H} 10), 7.06(2 \mathrm{H}, \mathrm{t}, \mathrm{J}=8.61 \mathrm{~Hz}, \mathrm{H} 15), 7.26(2 \mathrm{H}, \mathrm{dd}, \mathrm{J}=8.64,4.34 \mathrm{~Hz}, \mathrm{H} 16), 7.75$ (1H, s, H12), $7.82(1 \mathrm{H}, \mathrm{s}, \mathrm{H} 8) .{ }^{13} \mathrm{C} \mathrm{NMR}\left(100.61 \mathrm{MHz}, \mathrm{CDCl}_{3}\right): \delta=27.99\left(\mathrm{~N} 1-\mathrm{CH}_{3}\right), 29.82\left(\mathrm{~N} 3-\mathrm{CH}_{3}\right), 41.47$ (C10), 53.58 (C13), 106.45 (C5), 116.09 (C15), 116.31 (C15), 123.39 (C12), 129.98 (C16), 130.06 (C16), 141.35 (C8), 142.65 (C11), 148.99 (C4), 151.59 (C2), 155.44 (C6), 161.69 (C14 or C17), 164.17 (C14 or C17). FT-IR/ATR vmax/cm-1: 3144.88, 3116.27, 3000.48, 2960.31, $1691.08,1651.91,1549.09,1512.06,1456.51,1226.98,1023.54,786.67,750.59,615.31,522.38$. HRMS (ESI-TOF) (calculated for $\mathrm{C}_{17} \mathrm{H}_{17} \mathrm{~N}_{7} \mathrm{O}_{2} \mathrm{~F}+\mathrm{H}+$ ): 370.1422 ; found: 370.1419 .

3.1.4. 7-((1-(4-chlorobenzyl)-1H-1,2,3-triazol-4-yl) methyl)-1,3-dimethyl-3,7-dihydro-1H-purine-2,6-dione (5).

Compound 5 was synthesized following the procedure described for compound 3, from compound 2 and 4chlorobenzyl chloride. Compound 5 is obtained, after chromatographic purification $\left(\mathrm{CH}_{2} \mathrm{Cl}_{2}\right.$ : EtOH 95:5), as a light green powder: yield 76\%, m.p. 194-196 ${ }^{\circ} \mathrm{C} .{ }^{1} \mathrm{H}$ RMN (400.13 MHz, $\left.\mathrm{CDCl}_{3}\right)$ : $\delta=3.39\left(3 \mathrm{H}, \mathrm{s}, \mathrm{N} 1-\mathrm{CH}_{3}\right), 3.56(3 \mathrm{H}, \mathrm{s}, \mathrm{N} 3-$ $\left.\mathrm{CH}_{3}\right), 5.47(2 \mathrm{H}, \mathrm{s}, \mathrm{H} 13), 5.56(2 \mathrm{H}, \mathrm{s}, \mathrm{H} 10), 7.20(2 \mathrm{H}, \mathrm{d}, \mathrm{J}=8.42 \mathrm{~Hz}, \mathrm{H} 15), 7.34(2 \mathrm{H}, \mathrm{d}, \mathrm{J}=842 . \mathrm{Hz}, \mathrm{H} 16), 7.77$ (1H, s, H12), $7.82(1 \mathrm{H}, \mathrm{s}, \mathrm{H} 8) .{ }^{13} \mathrm{C}$ NMR $\left(100.61 \mathrm{MHz}, \mathrm{CDCl}_{3}\right):$ o= $27.98\left(\mathrm{~N} 1-\mathrm{CH}_{3}\right), 29.81\left(\mathrm{~N} 3-\mathrm{CH}_{3}\right), 41.45(\mathrm{C} 10), 53.58(\mathrm{C} 13), 106.45$ (C5), 123.53 (C12), 129.38 (C15), 129.44 (C16), 132.72 (C14), 135.01 (C17), 141.36 (C8), 142.77 (C11), 149 (C4), 151.58 (C2), 155.44 (C6). FT-IR/ATR vmax/cm-1: 3096.88, 3052.15, 2960.28, 1688.25, 1650.83, 1555.24, 1406.79, 1220.94, 1082.17, 1045.89, 978.31, 848.97, 785.63, 770.92, 608.01, 494.81. HRMS (ESI-TOF) (calculated for $\mathrm{C}_{17} \mathrm{H}_{17} \mathrm{~N}_{7} \mathrm{O}_{2} \mathrm{Cl}+\mathrm{H}+$ ): 386.1127; found: 386.1124 .

3.1.5. 7-((1-(4-bromobenzyl)-1H-1,2,3-triazol-4-yl) methyl)-1,3-dimethyl-3,7-dihydro-1H-purine-2,6-dione (6).

Compound 6 was synthesized following the procedure described for compound 3, from compound 2 and 4bromobenzyl bromide. Compound 6 is obtained, after chromatographic purification $\left(\mathrm{CH}_{2} \mathrm{Cl}_{2}: \mathrm{EtOH} 95: 5\right)$, as a white powder: yield 63\%, m.p. $199-201{ }^{\circ} \mathrm{C} .{ }^{1} \mathrm{H}$ RMN $\left(500.13 \mathrm{MHz}, \mathrm{CDCl}_{3}\right): \delta=3.39\left(3 \mathrm{H}, \mathrm{s}, \mathrm{N} 1-\mathrm{CH}_{3}\right), 3.56\left(3 \mathrm{H}, \mathrm{s}, \mathrm{N} 3-\mathrm{CH}_{3}\right)$, $5.45(2 \mathrm{H}, \mathrm{s}, \mathrm{H} 13), 5.56(2 \mathrm{H}, \mathrm{s}, \mathrm{H} 10), 7.13(2 \mathrm{H}, \mathrm{d}, \mathrm{J}=8.65 \mathrm{~Hz}, \mathrm{H} 15), 7.49$ (2H, d, J= $8.61 \mathrm{~Hz}, \mathrm{H} 16), 7.76$ (1H, s, H12), 7.80 $(1 \mathrm{H}, \mathrm{s}, \mathrm{H} 8) .{ }^{13} \mathrm{C}$ NMR $\left(125.77 \mathrm{MHz}, \mathrm{CDCl}_{3}\right): \mathrm{\delta}=27.96\left(\mathrm{~N} 1-\mathrm{CH}_{3}\right), 29.79\left(\mathrm{~N} 3-\mathrm{CH}_{3}\right), 41.46(\mathrm{C} 10), 53.62(\mathrm{C} 13), 106.45$ (C5), 123.09 (C17), 123.49 (C12), 129.69 (C15), 132.33 (C16), 133.24 (C14), 141.31 (C8), 142.81 (C11), 149 (C4), 151.56 (C2), 155.42 (C6). FT-IR/ATR vmax/cm-1: 3134.60, 3095.80, 3049.46, 2960.09, 1687.19, 1650.07, 1554.67, 1450.68, 1405.55, $1220.14,1103.66,1030.53,978.62,847.88,607.67,488.92$. HRMS (ESI-TOF) (calculated for $\mathrm{C}_{17} \mathrm{H}_{17} \mathrm{~N}_{7} \mathrm{O} 2 \mathrm{Br}+\mathrm{H}+$ ): 430.0621; found: 430.0618 .

3.1.6. 7-((1-(4-iodobenzyl)-1H-1,2,3-triazol-4-yl) methyl)-1,3-dimethyl-3,7-dihydro-1H-purine-2,6-dione (7).

Compound 7 was synthesized following the procedure described for compound 3, from compound 2 and 4iodobenzyl bromide. Compound 7 is obtained, after chromatographic purification $\left(\mathrm{CH}_{2} \mathrm{Cl}_{2}: \mathrm{EtOH} 95: 5\right)$, as a white powder: yield $68 \%$, m.p. $181-184{ }^{\circ} \mathrm{C} .{ }^{1} \mathrm{H}$ NMR $\left(400.13 \mathrm{MHz}, \mathrm{CDCl}_{3}\right): \delta=3.39\left(3 \mathrm{H}, \mathrm{s}, \mathrm{N} 1-\mathrm{CH}_{3}\right), 3.56\left(3 \mathrm{H}, \mathrm{s}, \mathrm{N} 3-\mathrm{CH}_{3}\right)$, $5.44(2 \mathrm{H}, \mathrm{s}, \mathrm{H} 13), 5.56(2 \mathrm{H}, \mathrm{s}, \mathrm{H} 10), 7.00(2 \mathrm{H}, \mathrm{d}, \mathrm{J}=8.38 \mathrm{~Hz}, \mathrm{H} 15), 7.69(2 \mathrm{H}, \mathrm{d}, \mathrm{J}=8.37 \mathrm{~Hz}, \mathrm{H} 16), 7.76(1 \mathrm{H}, \mathrm{s}, \mathrm{H} 12), 7.82$ $(1 \mathrm{H}, \mathrm{s}, \mathrm{H} 8) .{ }^{13} \mathrm{C}$ NMR $\left(100.61 \mathrm{MHz}, \mathrm{CDCl}_{3}\right)$ : $\delta=28.02\left(\mathrm{~N} 1-\mathrm{CH}_{3}\right), 29.84\left(\mathrm{~N} 3-\mathrm{CH}_{3}\right), 41.46(\mathrm{C} 10), 53.73(\mathrm{C} 13), 94.76(\mathrm{C} 17)$, 106.44 (C5), 123.54 (C12), 129.88 (C15), 133.88 (C14), 138.29 (C16), 141.35 (C8), 142.72 (C11), 148.98 (C4), 151.58 (C2), 


\section{R. Soc. open sci. article template}

4 Insert your short title here

155.43 (C6). FT-IR/ATR vmax/cm-1: 3143.55, 3115.45, 2958.37, 1690.45, 1651.19, 1548.13, 1456.04, 1218.88, 1006.66, 750.30, 615.40, 498.95. HRMS (ESI-TOF) (calculated for $\mathrm{C}_{17} \mathrm{H}_{17} \mathrm{~N}_{7} \mathrm{O}_{2} \mathrm{I}+\mathrm{H}+$ ): 478.0483; found: 478.0478.

\subsection{Corrosion inhibition tests}

\subsubsection{API 5L X52 steel}

API 5L X52 steel was used for the corrosion inhibition studies. This type of steel has a metallographic preparation with the following nominal composition (wt\%): C, 0.025; Mn, 1.65; Si, 0.26; Ti, 0.015; V, 0.001; Nb, 0.068; Mo, 0.175; S, $0.0025 ; \mathrm{Al}, 0.045 ; \mathrm{Ni}, 0.08 ; \mathrm{Cr}, 0.07 ; \mathrm{Cu}, 0.21$; and balance iron.

\subsubsection{Inhibitor solutions}

A 0.01 M solution of each theophylline-triazole inhibitor 3-7 in DMF was prepared. Then, concentrations of 5, 10, 20 and $50 \mathrm{ppm}$ of the inhibitor were added to the $1 \mathrm{M} \mathrm{HCl}$ corrosive solution.

\subsubsection{Characterization of surfaces by SEM-EDS}

The API 5L X52 steel surface was prepared both without (blank) and with inhibitor; a 50-ppm concentration was used for a $24 \mathrm{~h}$ immersion time. After that experiment, the steel was washed with distilled water, dried, and the surface analysed using a Zeiss SUPRA 55 VP electronic sweep microscope at $10 \mathrm{kV}$ with a 300x secondary electron detector.

\subsubsection{Electrochemical evaluation}

The potential was stabilized at $20^{\circ} \mathrm{C}$ for approximately $1800 \mathrm{~s}$ before electrochemical impedance spectroscopy (EIS) test. EIS: a sinusoidal potential of $\pm 10 \mathrm{mV}$ was applied in a frequency interval of $10^{-2} \mathrm{~Hz}$ to $10^{4} \mathrm{~Hz}$, in an electrochemical cell with three electrodes using Gill Ac. The working electrode was API 5L X52 steel, while reference electrode and counter electrode were $\mathrm{Ag} / \mathrm{AgCl}$ saturated with chloride potassium and graphite respectively. The electrode surface was prepared using conventional metallography methods over an exposed area of $1 \mathrm{~cm}^{2}$. After EIS measurements, the potentiodynamic polarization curves of 5 and $50 \mathrm{ppm}$ of inhibitors were obtained. The measurements covered a range from $-500 \mathrm{mV}$ to $500 \mathrm{mV}$ regarding the open circuit potential (OCP), with a sweep velocity of $66.07 \mathrm{mV}$ min-1 using the ACM Analysis software for data interpretation.

\section{Results and Discussion}

\subsection{EIS Electrochemical evaluation}

After obtaining the Nyquist diagrams of the compounds at different concentrations, the results were adjusted using the equivalent electric circuits (Fig. 2), to obtain the resistances: $R s$ is the solution resistance, $R_{\mathrm{ct}}$ is the resistance to charge transference and $Q$ is the constant phase element, $R_{\text {mol }}$ is the molecules resistance.

The value of inhibition efficiency $(\eta)$ can be obtained using the following equation [33-34]:

$$
\eta(\%)=\frac{\left(\frac{1}{R \mathrm{p}}\right) \text { blank }-\left(\frac{1}{R \mathrm{p}}\right) \text { inhibitor }}{\left(\frac{1}{R \mathrm{p}}\right) \text { blank }} \times 100
$$

Fig. 3 corresponds to the Nyquist diagram for the system without inhibitor, which depicts a depressed semicircle reaching a maximum $Z$ real value of $30 \Omega \mathrm{cm}^{2}$ (adjusted with electrical circuit Figure 2a).

In Figs. 4a-4e the Nyquist diagrams of each of the theophylline-triazoles are shown. As can be seen, the diameter of the semicircle increases proportionally with the inhibitor's concentration. According to the shape of the semicircle, two time constant (using the circuit Figure 2b) can be attributed, the charge transference resistance and the second 
to adsorbed molecules resistance [35-37]. It can be observed that the Zreal value presents a large variation. Based on these results, it can be inferred that the presence of a halogen substituent in para position of the aromatic ring modulate the inhibition capacity of the compound.

In the electrochemical parameters obtained from the adjustment of experimental data with the equivalent circuit shown previously, it is possible to notice that the value of the capacitance of the electrochemical double layer $\left(C_{\mathrm{dl}}\right)$ decreases when more concentration of the inhibitor is added, due to the gradual displacement of water molecules with the theophylline-triazole inhibitor molecules in the working electrode, which decreases the number of active sites and consequently delays the corrosion phenomenon [38-39]. The charge transference resistance $\left(R_{\mathrm{ct}}\right)$ also increases when more concentration of the inhibitor is added in every case. Finally, the value of the inhibition efficiency reached a maximum of $94 \%$ of effectivity at $50 \mathrm{ppm}$ for the compound containing chloride in its chemical structure.

In Fig. 5, a comparative of inhibition efficiency values for each theophylline-triazole derivative is shown. It is important to mention that, for the lowest concentration measurements (5 ppm), the best inhibition efficiency is presented by compound 7 .

At lower inhibitor concentrations (5 ppm) the adsorbability effect was observed to follow the order $\mathrm{F}$ (compound 4$)<\mathrm{Cl}$ (compound 5) $<\mathrm{Br}$ (compound 6) $<\mathrm{H}$ (compound 3) $<\mathrm{I}$ (compound 7). The later can be attributed to the larger size and the great polarizability on I, facilitating electron pair bonding and effectively enhancing the inhibiting power. However, the presence of the halogen attached to the benzene ring does not show a clear trend in the improvement of the inhibition efficiency at the highest inhibitor concentration (50 ppm), because it is not the only fragment that is interacting with the metal surface [39]. At the highest concentration $(50 \mathrm{ppm})$, the best inhibition efficiency is presented by compound $5(\eta(\%)=94)$, followed closely by compound 3 and $\mathbf{6}(\eta(\%) \sim 91)$. The best inhibition (compound 5) can be attributed to the increased electron affinity of $\mathrm{Cl}$, that could create a partially negative charge that can interact more efficiently with the positively charged metal surface, enhancing the overall adsorption of the molecule and thus, increasing its corrosion inhibition efficiency.

Also, worth to mention is the fact that the corrosion inhibition efficiency of all the theophylline-triazole derivatives is higher than the corrosion inhibition observed in the underivatized theophylline [23] but is comparatively lower than other 1,2,3-triazole derivatives reported earlier [28-30].

\section{Potentiodynamic polarization evaluation}

The potentiodynamic polarization curves of the API 5L X52 steel immerse in $\mathrm{HCl} 1 \mathrm{M}$ in absence and presence of triazoles 1,4-disubstituted ( 5 and 50 ppm) are shown in Fig. 6. The parameters as the corrosion potential ( $\left.E_{\text {corr }}\right)$, Tafel anodic pendant $(\mathrm{ba})$, cathodic pendant $(\mathrm{bc})$, and corrosion current density (icorr) obtained from the curves are shown in Table 2.

The inhibition efficiency $\left(\eta_{\mathrm{pol}}\right)$ is calculated with the following equation [40-42]:

$$
\eta_{\text {pol }}(\%)=\frac{i_{\text {corr blank }}-i_{\text {corr inhibitor }}}{i_{\text {corr blank }}} \times 100
$$

Where icorr is the corrosion current density in absence (blank) and presence (inhibitor) of the inhibitor.

In Table 2, the electrochemical parameters are summarized. The corrosion current density decrements can be attributed to the adsorption of the organic compound on the metal surface in the acidic medium, which generates a protecting barrier that effectively blocks the active sites on the metal [43].

On the other hand, the corrosion potential ( $\left.E_{\text {corr }}\right)$ is lesser than $85 \mathrm{mV}$, which suggests that it belongs to the mixed type with cathodic predominance for the two concentrations studied [44]. 
It is worth noting that the inhibition efficiency was also calculated by this technique for two concentrations of each organic compound (summarized in Table 2), which closely correlate with the results obtained by the EIS technique.

\section{Adsorption Isotherm}

Among all the adsorption mechanism descriptions reported in the literature [45-48], the most common model to describe this process is Langmuir's isotherms (equation 3). The corresponding adjustment for this model was performed, and the adjustment parameters are shown in Table 3.

$$
\frac{C}{\theta}=\frac{1}{\mathrm{~K}_{\mathrm{ads}}}+C
$$

Where $C$ is the concentration, $\theta$ is the coating degree and $K_{\text {ads }}$ is the adsorption constant.

The value of $K_{\text {ads }}$ is related with the Gibbs free energy value ( $\Delta \mathrm{G}^{\circ}$ ads) and is related to the following equation [49]:

$$
\Delta G_{a d s}^{\circ}=-R T \ln \left(55.5 K_{a d s}\right)
$$

Where the numeric value of 55.5 is the molar concentration of water in an acid solution, $R$ is the constant of ideal gasses and $T$ is the absolute temperature of the system.

The calculated values of the thermodynamic adjustment are also shown in Table 3. Several authors mention that the values of $\Delta \mathrm{G}^{\circ}$ ads around $-40 \mathrm{KJ} / \mathrm{mol}$ or more negative are consistent with the charge interchange between the metal and the organic compound, so the reaction is defined as a chemisorption, while the values of $\Delta \mathrm{G}^{\circ}$ ads lower than $-20 \mathrm{KJ} / \mathrm{mol}$ produce only an electrostatic interaction (physisorption) [50-51].

According to these results, the compounds 3, 6 and 7 presents chemisorption process and, for the rest of the compounds, a physisorption-chemisorption type process is observed [52-54].

\section{SEM-EDS Surface analysis}

The surfaces of the API 5L X52 steel with and without inhibitor (fig. 8), were characterized by SEM- EDS to corroborate the effectiveness of the inhibitor by evaluating the electrochemical response. Figure 8 a shows the surface of polished steel, while in figure $8 c$, shows the steel surface after 24 hours of immersion in a solution of $\mathrm{HCl} 1 \mathrm{M}$. As can be seen, the metallic surface presents damage due to the presence of chloride ions in the corrosive solution, supported by EDS and shown in Fig. 8d. Finally, figures 8e and 8f shows the morphology of the metallic surface in presence of the best organic inhibitors found in this research (compounds 5 and 7). These results suggest that the inhibitors form protective films of the surface of the API 5L X52 steel effectively diminishing corrosion. In this case, the corrosive species $\left(\mathrm{Cl}^{-1}\right)$ are not observed in the chemical analysis (Figures $8 \mathrm{f}$ and $8 \mathrm{~h}$ ).

\section{Conclusion}

The theophylline-triazole derivatives synthesized by heterogeneous catalysis were obtained in good yields. These compounds were evaluated as corrosion inhibitors in API 5L X52 steel, demonstrating that the inhibition activity of the theophylline- triazole derivatives is greater than the inhibition activities of any xanthine derivatives as theophylline, and theobromine.

The best inhibitors are the ones bearing a chloride (compound 5) and iodine (compound 7) substituents at the para position of the aromatic ring. The best inhibition activity is reached at a concentration of $50 \mathrm{ppm}(\eta$ of $94 \%$ ). Compound 4 is the least efficient as a corrosion inhibitor, containing halogen fluoride. As expected, the presence of an electron withdrawing atom in the phenyl ring decreases the overall efficiencies as corrosion inhibitors of the compounds. This trend is more noticeable at lower inhibitor concentrations. 
The adsorption study for compounds 3-7 showed that the corrosion inhibition process follows the Langmuir isotherm, with a combined physisorption-chemisorption process for compounds 3, 6 and 7. Finally, the inhibitors that carried out chemisorption process are compounds 4 and 5.

\section{Data Availability}

Experimental NMR and IR data can be downloaded from https://datadryad.org/review?doi=doi:10.5061/dryad.rs72388

doi:10.5061/dryad.rs72388

\section{Acknowledgments}

The authors thank CONACYT for the financial support granted for the development of this research through the project P43984-Q.

The authors also thank the Divisional Microscopy Laboratory of the Autonomous Metropolitan University Unit Azcapotzalco for the use of the Scanning Electron Microscope SUPRA 55 VP.

AEV and FJRG express their gratitude to the School of Chemistry (UNAM), Department of Metallurgic Engineering, and CONACyT for providing a postdoctoral fellowship.

\section{Competing Interests}

We have no competing interests.

\section{Authors' Contributions}

Araceli Espinoza Vazquez carried out the experiments, analyzed and interpretation of data by electrochemical evaluation, Deyanira Ángeles Beltrán performed the surface characterization. Francisco Javier Rodríguez Gómez and Manuel Palomar Pardavé supervised all the electrochemical experiments. Guillermo E. Negrón Silva, Leticia Lomas Romero and Diego Pérez Martínez supervised the synthesis and characterization of all the triazole-theophylline compounds. Ivonne Karina Martínez Cruz was responsible for the synthesis and purification of organic compounds.

All the authors gave their final approval for publication

\section{References}

1. Machuca LL, Lepkova K and Petroski A. 2017. Corrosion of carbon steel in the presence of oilfield deposit and thiosulphate-reducing bacteria in $\mathrm{CO}_{2}$ environment. Corros. Sci. 129, 16-25.

2. Azzaoui K, Mejdoubi E, Jodeh S, Lamhamdi A, Rodriguez-Castellón $E$, Algarra M, Zarrouk A, Errich A, Salghi R, Lgaz H. 2017. Eco friendly green inhibitor Gum Aracbic (GA) for the corrosion control of mild steel in hydrochloric acid medium. Corros. Sci., 129, 70-81.

3. Winkier DA, Breedon $M$, White $P$, Hughes AE, Sapper ED, Cole I. 2016. Using high throughput experimental data and in silico models to discover alternatives to toxic chromate corrosion inhibitors. Corros. Sci., 106 229-235.

4. Benali O, Selles C, Salghi R. 2014. Inhibition of acid corrosion of mild steel by Anacyclus pyrethrum L. extracts. Res. Chem. Intermed. 40, 259-268.

5. Karthikeyan S. 2016. Drugs/Antibiotics as potential corrosion inhibitors for Metals - A Review. Int. J. Chem. Tech. Res. 9, 251-259.

6. Sanaei Z, Bahlakeh G, Ramezanzandeh B. 2017. Active corrosion protection of mild steel by an epoxy ester coating reinforced with hybrid organic/inorganic green inhibitive pigment. J. Alloys Compd., 718, 1289-1304.

7. Solmaz R, Kardaş G, Yazıcı B, Erbil M. 2008. Adsorption and corrosion inhibitive properties of 2-amino-5mercapto-1,3,4-thiadiazole on mild steel in hydrochloric acid media. Colloids Surf., A, 312, 7-17.

8. Tao Z, He W, Wang S, Zhang S, Zhou G. 2012. A study of differential polarization curves and thermodynamic properties for mild steel in acidic solution with nitrophenyltriazole derivative, Corros. Sci. 60, 205-213.

9. Guo L, Qi C, Zheng X, Zhang R, Shen X, Kaya S. 2017. Toward understanding the adsorption mechanism of large size organic corrosion inhibitors on an Fe (110) surface using the DFTB method. RSC Adv. 7, 29042-29050.

10. Cao Z, Tang Y, Cang H, Xu J, Lu G, Jing W. 2014. Novel benzimidazole derivatives as corrosion inhibitors of mild steel in the acidic media. Part II: Theoretical studies, Corros. Sci. 83, 292-298.

11. Guo L, Obot IB, Zheng X, Shen X, Qiang Y, Kaya S, Kaya C. 2017, Theoretical insight into an empirical rule about organic corrosion inhibitors containing nitrogen, oxygen, and sulfur atoms, Appl. Surf. Sci. 406, 301-306.

12. Sığırcık G, Tüken T, Erbil M. 2016. Assessment of the inhibition efficiency of 3,4diaminobenzonitrile against the corrosion of steel, Corros. Sci. 102, 437-445.

13. Espinoza A, Negrón GE, González R., Ángeles $\mathrm{D}$, Romero $\mathrm{M}$, Palomar $\mathrm{M}$. 2017. Effect of Hydrodynamic Conditions, Temperature and Immersion Times on the Corrosion Inhibition Efficiency of API 5L X52 
Steel in $1 \mathrm{M} \mathrm{HCl}$ Containing $1 \mathrm{H}-1,2,4$ or 1H-1,2,3-triazoles, Arab J. Sci. Eng., 42, 163-170.

14. Salarvand Z, Amirnasr M, Talebian M, Raeissi K, Meghdadi S. 2017. Enhanced corrosion resistance of mild steel in $1 \mathrm{M} \mathrm{HCl}$ solution by trace amount of 2-phenylbenzothiazole derivatives: Experimental, quantum chemical calculations and molecular dynamics (MD) simulation studies, Corros. Sci. 114, 133-145.

15. Bansal R, Kumar G, Rohilla S, Klotz K. N, Kachler S, Young LC, Harvey AL. 2016. Synthesis and evaluation of a New series of 8-(2Nitroaryl)xantines as adenosine receptor ligands. Drug Dev. Res. 77, 241-250.

16. El Sayed Aly MR, Saad HA, Mosselhi M. A. 2015. Click reaction-based synthesis, antimicrobial, and cytotoxic activities of new 1,2,3triazoles, Med. Chem. Lett. 25, 2824-2830.

17. Ruddarraju RR, Murugulla AC, Kotla $R$, Tirumalasetty $M C B$, Wudayagiri R, Donthabakthuni S, Maroju R. 2017. Design, synthesis, anticancer activity and docking studies of theophylline containing 1,2,3triazoles with variant amide derivatives. Med. Chem. Commun. 8, 176-183.

18. Soltani MN, Behrouz S, Najafi H. 2014. N-Tosyltheophylline (TsTh): A highly Efficient reagent for the onepot synthesis of $\mathrm{N}$ alkyltheophyllines from alcohols. Synthesis, 46, 1380-1388.

19. Andrs $M$, Muthna $D$, Rezacova $M$, Seifrtova M, Siman P, Korabecny J, Benek O, Dolezal R, Soukup O, Jun D, Kuca K. 2016. Novel caffeine derivatives with antiproliferative activity. RSC Adv. 6, 32534-32539.

20. Hayallah AM, Elgaher WA, Salem O. I, Abdel AAM. 2011. Design and synthesis of some new theophylline derivatives with bronchodilator and antibacterial activities. Arch. Pharm. Res. 34, 3-21.

21. Ruddarraju RR, Murugulla AC, Kotla $R$, Tirumalasetty $M C B$, Wudayagiri R, Donthabakthuni S, Maroju R, Baburao K, Parasa LS. 2016. Design, synthesis, anticancer, antimicrobial activities and molecular docking studies of theophylline containing acetylenes and theophylline containing 1,2,3-triazoles with variant nucleoside derivatives, Eur. J. Med. Chem. 123, 379-396.

22. Cuong NT, Tai TB, Thu Ha VT, Nguyen M. T. 2010. Thermochemical parameters of caffeine, theophylline and xanthine. J. Chem. Thermodyn., 42, 437-440.

23. De Souza FS, Giacomelli C, Gonçalves RS, Spinelli A. 2012. Assessment of caffeine adsorption onto mild steel surface as an ecofriendly corrosion inhibitor, Mater. Sci. Eng. C Mater. Biol. Appl. 32, 2436.

24. Espinoza A, Rodríguez FJ, Martínez IK, Negrón GE, Palomar M. 2018. Determination of Inhibition Properties of Caffeine, Theophylline and their Allylic and Propargylic Derivatives on API $5 \mathrm{~L}$ X70 Steel Immerse in $1 \mathrm{M} \mathrm{HCl}$. ECS transactions, 84(1) 165-171.

25. Ma Q, Qi S, He X, Tanga Y, Lub G. 2017. 1,2,3-Triazole derivatives as corrosion inhibitors for mild steel in acidic medium: Experimental and computational chemistry studies, Corros. Sci. 129, 91-101.

26. AL Jahdaly BA, Awad MI. 2016. Enhanced inhibition of corrosión of mild Steel by triazole derivative in presence of copper ions. Int. J. Electrochem. Sci. 11, 5473-5480.

27. Ofoegbu SU, Galvão TLP, Gomes J. RB, Tedim J, Nogueira HIS, Ferreira MGS, Zheludkevich ML. 2017. Corrosion inhibition of copper in aqueous chloride solution by $1 \mathrm{H}$ 1,2,3-triazole and 1,2,4-triazole and their combinations: electrochemical, Raman and theoretical studies, Phys. Chem. Chem. Phys. 19, 6113-6129.

28. Yan $Y$, Lin X, Zhang L, Zhou H, Wu L, Cai L. 2017. Electrochemical and quantum-chemical study on newly synthesized triazoles as corrosion inhibitors of mild steel in $1 \mathrm{M} \mathrm{HCl}$, Res. Chem. Intermed. 43, 31453154.

29. Espinoza A, Rodríguez FJ, Vergara BI, Lomas L, Ángeles D, Negrón GE, Morales JA. 2017. Synthesis of 1,2,3-triazoles in the presence of mixed $\mathrm{Mg} / \mathrm{Fe}$ oxides and their evaluation as corrosion inhibitors of API $5 \mathrm{~L}$ X70 steel submerged in $\mathrm{HCl}$, RSC Adv. 7, 24736-24746.

30. González R, Román V, Negrón GE, Espinoza A, Rodríguez FJ, Santillán R. 2016. Multicomponent Synthesis and Evaluation of New 1,2,3Triazole Derivatives of Dihydropyrimidinones as Acidic Corrosion Inhibitors for Steel, Molecules, 21, 250-3-13.

31. Espinoza A, Negrón GE, González R, Ángeles D, Herrera H, Romero $M$, Palomar M. 2014. Mild steel corrosion inhibition in $\mathrm{HCl}$ by dialkyl and di-1,2,3-triazole derivatives of uracil and Thymine. Mater. Chem. Phys., 145, 407-417.

32. Espinoza A, Rodríguez FJ, González R, Ángeles D, Mendoza D, Negrón G E, 2016. Electrochemical assessment of phenol and triazoles derived from phenol (BPT) on API $5 \mathrm{~L}$ X52 steel immersed in $1 \mathrm{M} \mathrm{HCl}$. RSC Adv., 6, 72885-72896.

33. Obayes HR, Al-Amiery AA, Alwan $\mathrm{G}$ $H$, Amir A, Kadhum $H$, Mohamad A
B. 2017. Sulphonamides as corrosion inhibitor: Experimental and DFT studies. J. of Mol. Struct. 1138, 27-34

34. Obot IB, Ankah NK, Sorour AA, Gasem ZM, Haruna K. 2017. 8Hydroxyquinoline as an alternative green and sustainable acidizing oilfield corrosion inhibitor. Sust. Mat. and Techn., 14, 1-10

35. Pfeiffer $M$, Klock $H$, Helmut, Bergen G. Ehrenhaft, Ferreira P, Gollnick J., Fischer CB. 2017. Surface protection of low carbon steel with $\mathrm{N}$-acyl sarcosine derivatives as green corrosion inhibitors. Surf. Interfaces, 9, 70-78.

36. Qiang $Y$, Zhang S, Yan S, Zou X, Chen S. 2017. Three indazole derivatives as corrosion inhibitors of copper in a neutral chloride solution. Corros. Sci. 126, 295-304.

37. Yadav M, Behera D, Sharma U. 2016. Nontoxic corrosion inhibitors for N80 steel in hydrochloric acid. Arab. J. of Chem., 9(2), s1487s1495.

38. Mo S, Jie L, Qun H, Bing N. 2017. An example of green copper corrosion inhibitors derived from flavor and medicine: Vanillin and isoniazid. J. of Mol. Liq. 242, 822830

39. Zeino A, Abdulazeez I, Khaled M, Jawich MW, Obot IB. 2018. Mechanistic study of polyaspartic acid (PASP) as eco-friendly corrosion inhibitor on mild steel in $3 \% \mathrm{NaCl}$ aerated solution. J. of $\mathrm{Mol}$. Liq., 250, 50-62.

40. Singh $D$, Ansari KR, Sorour $A A$, Quraishi MA., Gaz HL, Salghi R. 2018. Thiosemicarbazide and thiocarbohydrazide functionalized chitosan as ecofriendly corrosion inhibitors for carbon steel in hydrochloric acid solution, Int. J. of Biol. Macrom. 107, 1747-1757.

41. Kadhim A, Al-Okbi AK, Jamil DM, Qussay A, Al-Amiery AA, Sumer T, Kadhum AAH, Mohamad AB, Nassir $\mathrm{MH}$. 2017. Experimental and theoretical studies of benzoxazines corrosion inhibitors, Results in Phys. 7, 4013-4019.

42. Chidiebere MA, Oguzie EE, Liu L, Li Y, Wang F. 2015. Adsorption and corrosion inhibiting effect of riboflavin on Q235 mild steel corrosion in acidic environments, Mat. Chem. and Phys. 156, 95-104.

43. Prabakaran M, HyunKim S, Mugila N, Hemapriya V, Parameswari K, Chitra S. 2017. Aster koraiensis as nontoxic corrosion inhibitor for mild steel in sulfuric acid, J. of Ind. and Eng. Chem. 52, 235-242.

44. Ansari KR, Quraishi MA, Singh A. 2017. Chromenopyridin derivatives as environmentally benign corrosion inhibitors for N80 steel in $15 \% \mathrm{HCl}$, J. of the Assoc. of Arab 
Universit. for Basic and Appl. Sci. 22, 45-54.

45. Hamani H, Douadi T, Daoud D, AlNoaimi M, Amina R, Chafaa S. 2017. 1-(4-Nitrophenylo-imino)-1(phenylhydrazono)-propan-2-one as corrosion inhibitor for mild steel in $1 \mathrm{M} \mathrm{HCl}$ solution: Weight loss, electrochemical, thermodynamic and quantum chemical studies. J. of Electroanal. Chem. 801, 425-438.

46. Bedair MA, El-Sabbah MMB, Fouda AS, Elaryian HM. 2017. Synthesis, electrochemical and quantum chemical studies of some prepared surfactants based on azodye and Schiff base as corrosion inhibitors for steel in acid medium, Corros. Sci. 128, 54-72.

47. Lee H, Abdul A, Yuen C, Saad B, Idris M, Umeda M. 2017. Aquilaria subintergra leaves extracts as sustainable mild steel corrosion inhibitors in $\mathrm{HCl}$. Meas. 109, 334345.
48. Shihab MS, Al-Doori HH. 2014. Experimental and theoretical study of [N-substituted] $p$ aminoazobenzene derivatives as corrosion inhibitors for mild steel in sulfuric acid solution, J. of $\mathrm{Mol}$. Struct. 1076, 658-663.

49. Singh P, Quraishi MA. 2016. Corrosion inhibition of mild steel using Novel Bis Schiff's Bases as corrosion inhibitors: Electrochemical and Surface measurement. Meas., 86, 114-124.

50. Hu K, Zhuang J, Zheng C, Ma Z, Ding J. 2016. Effect of novel cytosine-Ialanine derivative based corrosion inhibitor on steel surface in acidic solution. J. of Mol. Liq. 222, 109117.

51. Hu Z, Bin Y, MaX, Zhu H, Li J, Li C, Lin D. 2016, Experimental and theoretical studies of benzothiazole derivatives as corrosion inhibitors for carbon steel in $1 \mathrm{M} \mathrm{HCl}$, Corros. Sci., 112, 563-575.
52. Mobin M, Rizvi M. 2017. Polysaccharide from Plantago as a green corrosion inhibitor for carbon steel in $1 \mathrm{M} \mathrm{HCl}$ solution. Carbohydr. Polym. 160, 172-183.

53. Ostapenko GI, Gloukhov PA, Bunev AS, 2014. Investigation of 2cyclohexenylcyclohexanone as steel corrosion inhibitor and surfactant in hydrochloric acid. Corros. Sci., 82, 265-270.

54. Anupama KK, Ramya K, Shainy KM, Joseph A, 2015. Adsorption and electrochemical studies of Pimenta dioica leaf extracts as corrosion inhibitor for mild steel in hydrochloric acid, Mat. Chem. and Phys. 167, 28-41.

Tables

Table 1. Electrochemical parameters of 1,2,3-triazoles 1,4-disubstituted in API 5L X52 steel immerse in HCl 1M

\begin{tabular}{|c|c|c|c|c|c|c|c|c|}
\hline Inhibitor & $\begin{array}{c}\mathrm{C} \\
(\mathrm{ppm})\end{array}$ & $\begin{array}{c}\text { Rs } \\
\left(\Omega \mathrm{cm}^{2}\right)\end{array}$ & $\mathrm{n}$ & $\begin{array}{c}\mathrm{Cdl}_{\mathrm{dl}} \\
\left(\mu \mathrm{Fm}^{-2}\right)\end{array}$ & $\begin{array}{c}R_{\mathrm{ct}} \\
\left(\Omega \mathrm{cm}^{2}\right)\end{array}$ & $\begin{array}{c}R_{\mathrm{mol}} \\
\left(\Omega \mathrm{cm}^{2}\right)\end{array}$ & $\begin{array}{c}\eta \\
(\%)\end{array}$ & $\pm S D$ \\
\hline \multirow[t]{2}{*}{ blank } & 0 & 0.8 & 0.8 & 310.0 & 30 & - & - & - \\
\hline & 5 & 1.1 & 0.72 & 221.9 & 154.0 & 5.1 & 81.1 & 2.6 \\
\hline \multirow[t]{5}{*}{3} & 10 & 1.2 & 0.69 & 230.7 & 227.6 & 13.4 & 87.6 & 9 \\
\hline & 20 & 1.0 & 0.67 & 205.1 & 286.1 & 16.2 & 90.1 & 4.4 \\
\hline & 50 & 1.1 & 0.68 & 195.4 & 343.1 & 17.3 & 91.7 & 1.8 \\
\hline & 5 & 1.1 & 0.73 & 228.9 & 49.9 & 9.6 & 49.6 & 4.3 \\
\hline & 10 & 1.3 & 0.75 & 192.8 & 112.4 & 18.9 & 77.2 & 5.5 \\
\hline \multirow[t]{3}{*}{4} & 20 & 1.2 & 0.72 & 193.4 & 168.1 & 19.5 & 84.0 & 5.1 \\
\hline & 50 & 1.2 & 0.71 & 182.7 & 210.4 & 18.6 & 86.9 & 6 \\
\hline & 5 & 11.5 & 0.74 & 247.3 & 35.4 & 36.8 & 58.4 & 1.2 \\
\hline \multirow[t]{4}{*}{5} & 10 & 8.0 & 0.88 & 214.8 & 68.1 & 16.7 & 64.6 & 2.1 \\
\hline & 20 & 8.5 & 0.95 & 170.8 & 265.7 & 5.4 & 88.9 & 2.8 \\
\hline & 50 & 6.3 & 0.62 & 89.9 & 492.8 & 6.7 & 94.0 & 2.4 \\
\hline & 5 & 1.0 & 0.70 & 174.4 & 134.5 & 14.4 & 79.9 & 3.8 \\
\hline \multirow[t]{4}{*}{6} & 10 & 1.1 & 0.72 & 129.4 & 169.8 & 29.8 & 85.0 & 4.6 \\
\hline & 20 & 1.1 & 0.68 & 123.2 & 248.4 & 28.7 & 89.2 & 5.8 \\
\hline & 50 & 1.2 & 0.63 & 108.2 & 335.3 & 29.5 & 91.8 & 4.7 \\
\hline & 5 & 1.5 & 0.70 & 172.7 & 201.8 & 5.1 & 85.5 & 3.6 \\
\hline \multirow[t]{3}{*}{7} & 10 & 1.0 & 0.65 & 153.4 & 224.1 & 0.5 & 86.6 & 5.7 \\
\hline & 20 & 0.9 & 0.63 & 158.1 & 272.4 & 2.6 & 89.1 & 4.7 \\
\hline & 50 & 1.0 & 0.60 & 153.2 & 328.2 & 2.9 & 90.9 & 4.3 \\
\hline
\end{tabular}

Table 2. Electrochemical parameters obtained by means of polarization curves for 1,2,3-triazoles 1,4disubstited in API 5L X52 steel immerse in $\mathrm{HCl} 1 \mathrm{M}$

\begin{tabular}{llllll}
$C$ & $E_{\text {corr }}$ & bc & ba & $i_{\text {corr }}$ & $\eta_{\text {pol }}$ \\
\hline & & & R. Soc. open sci.
\end{tabular}




\begin{tabular}{c|cccccc} 
Inhibitor & $(\mathbf{p p m})$ & $\begin{array}{c}(\mathbf{m V}) \mathbf{v s} \\
\mathbf{A g} / \mathbf{A g C l}\end{array}$ & $\mathbf{( m V})$ & $\mathbf{( m V )}$ & $\mathbf{( m A / \mathbf { c m } ^ { 2 } )}$ & $\mathbf{( \% )}$ \\
\hline Blank & 0 & -421.2 & 106.5 & 84.6 & 0.32 & - \\
3 & 5 & -450.8 & 107.0 & 54.3 & 0.04 & 87.3 \\
3 & 50 & -470.1 & 109.5 & 75.0 & 0.04 & 86.9 \\
4 & 5 & -448.0 & 163.4 & 80.4 & 0.08 & 76.6 \\
4 & 50 & -439.9 & 158.8 & 74.7 & 0.04 & 87.0 \\
5 & 5 & -447.6 & 146.8 & 52.6 & 0.07 & 79.4 \\
5 & 50 & -441.0 & 110.2 & 66.3 & 0.02 & 71.0 \\
6 & 5 & -413.4 & 122.1 & 30.5 & 0.02 & 94.3 \\
6 & 50 & -427.2 & 136.2 & 48.4 & 0.02 & 93.5 \\
7 & 5 & -410.8 & 161.2 & 52.1 & 0.03 & 90.3 \\
7 & 50 & -425.3 & 132.2 & 69.5 & 0.04 & 88.2 \\
\end{tabular}

Table 3. Adjustment of thermodynamic data with the Langmuir isotherm

\begin{tabular}{c|cccc} 
Compound & $\begin{array}{r}\text { Ln } \\
\text { Kads }\end{array}$ & $\begin{array}{c}\Delta \mathrm{G}^{\circ} \text { ads } \\
\left(\mathrm{kJ} \mathrm{mol}^{-1}\right)\end{array}$ & Linear Regression Equation $(\mathrm{M})$ & $\mathrm{R}^{2}$ \\
\hline 3 & 17.1 & -41.7 & $\mathrm{C} / \theta=1.0 .759 \mathrm{C}+0.000002$ & 0.9982 \\
4 & 15.6 & -38.1 & $\mathrm{C} / \theta=1.0788 \mathrm{C}+0.000009$ & 0.9979 \\
5 & 15.5 & -37.8 & $\mathrm{C} / \theta=0.9749 \mathrm{C}+0.00001$ & 0.9965 \\
6 & 17.1 & -41.7 & $\mathrm{C} / \theta=1.0700 \mathrm{C}+0.000002$ & 0.9998 \\
7 & 17.8 & -43.4 & $\mathrm{C} / \Theta=1.0895 \mathrm{C}+0.000001$ & 0.9989
\end{tabular}

Figure and table captions

Figure 1 Synthesis of 1,2,3-triazoles in presence of $\mathrm{Cu}(\mathrm{Al}) \mathrm{O}$

Figure 2 Equivalent electric circuit used in the system with (b) and without inhibitor (a)

Figure 3 Nyquist diagram without inhibitor in immerse API 5L X52 steel

Figure 4 Nyquist diagrams of theophylline-triazoles in immerse API 5L X52 steel at different inhibitor concentrations. Diagrams a), b), c), d) and e) corresponds to compounds 3, 4, 5, 6 and 7 respectively

Figure 5 Variation of the inhibition efficiency of the theophylline-triazole derivatives 3-7 as a function of its concentration for API 5L X70 steel submerged in $1 \mathrm{M} \mathrm{HCl}$ by EIS technique.

Figure 6 Potentiodynamic polarization curves of 1,2,3-triazoles 1,4-disubstituted in API 5L X52 steel immerse in 1M of $\mathrm{HCl}$

Figure 7 Adjustment of the thermodynamic analysis of the theophylline-triazole derivatives by using a) Langmuir model and b) in API 5L X52 steel immerse in $\mathrm{HCl} 1 \mathrm{M}$

Figure 8 Images of SEM-EDS of API 5L X52 steel for a) polished steel, c) immerse in $\mathrm{HCl} \mathrm{1M}$ and in presence of 20 ppm of e) compound 5 and g) compound 7 


\section{FIGURE 1}

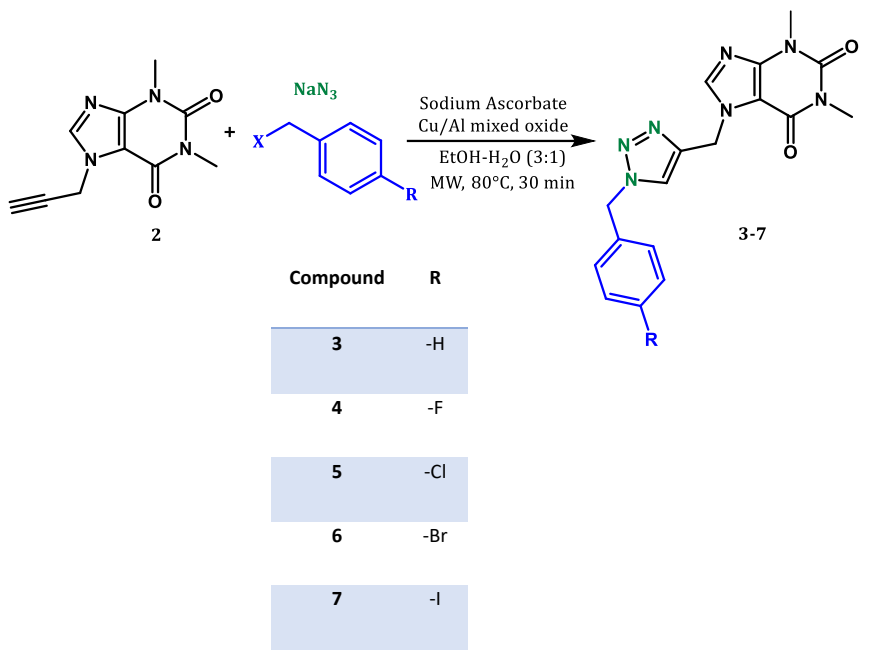


a)

b)
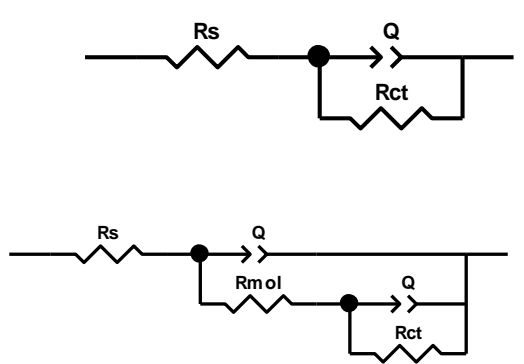


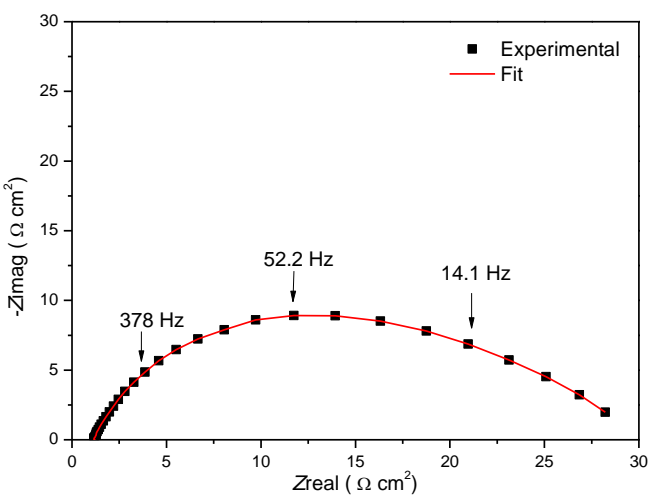



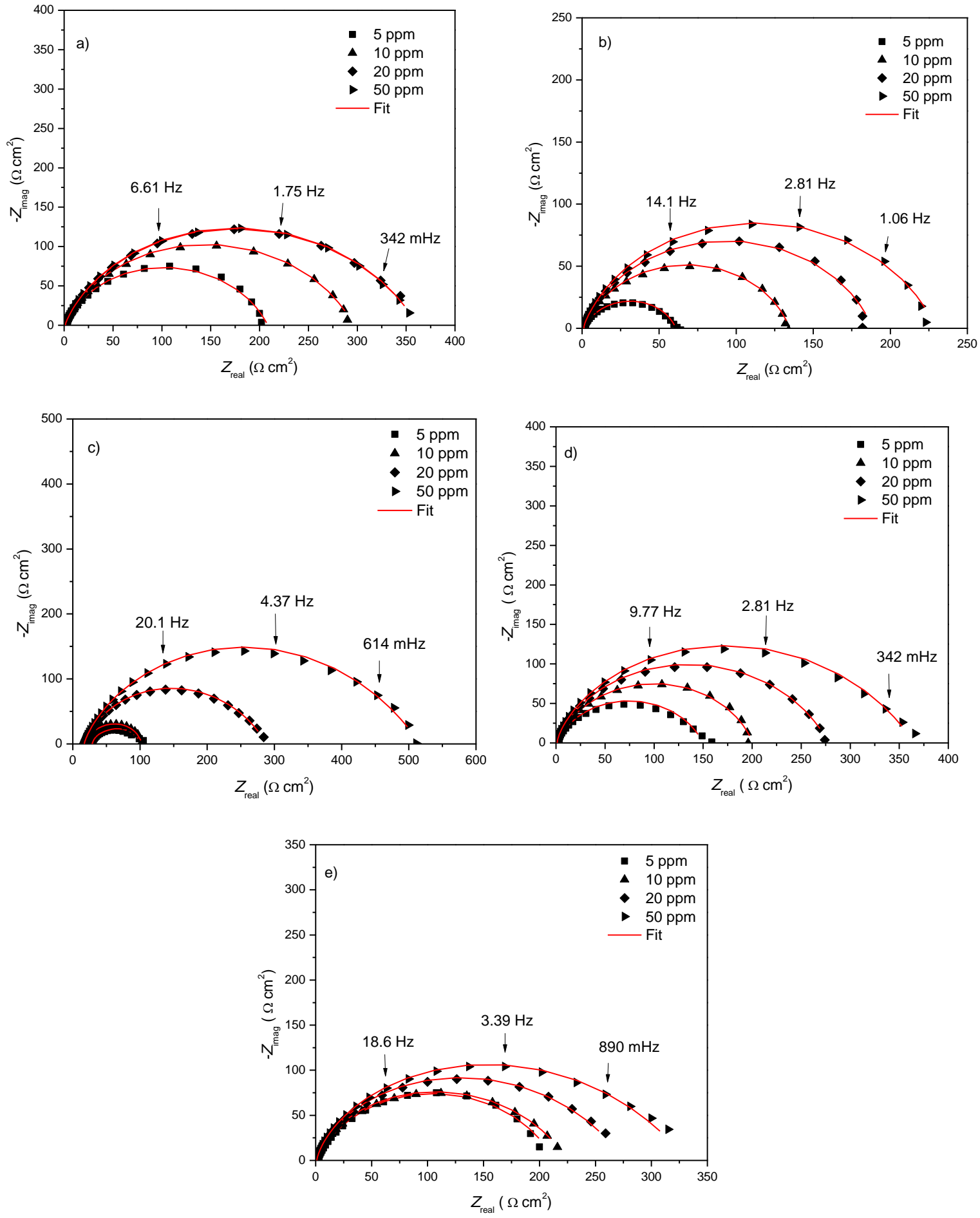


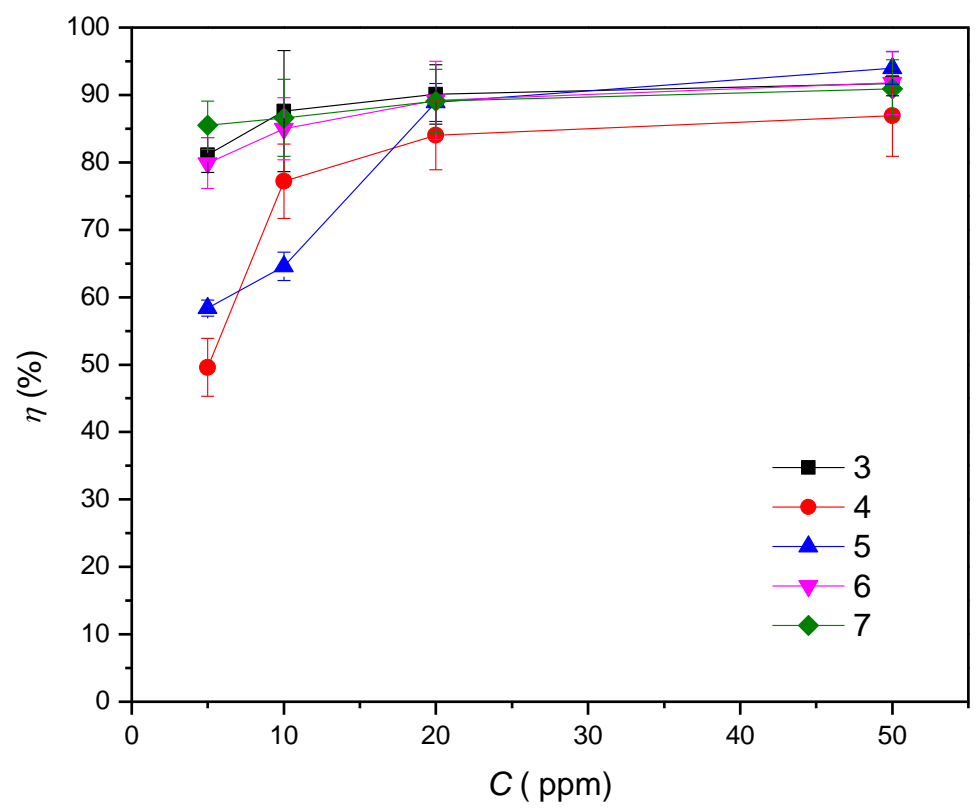



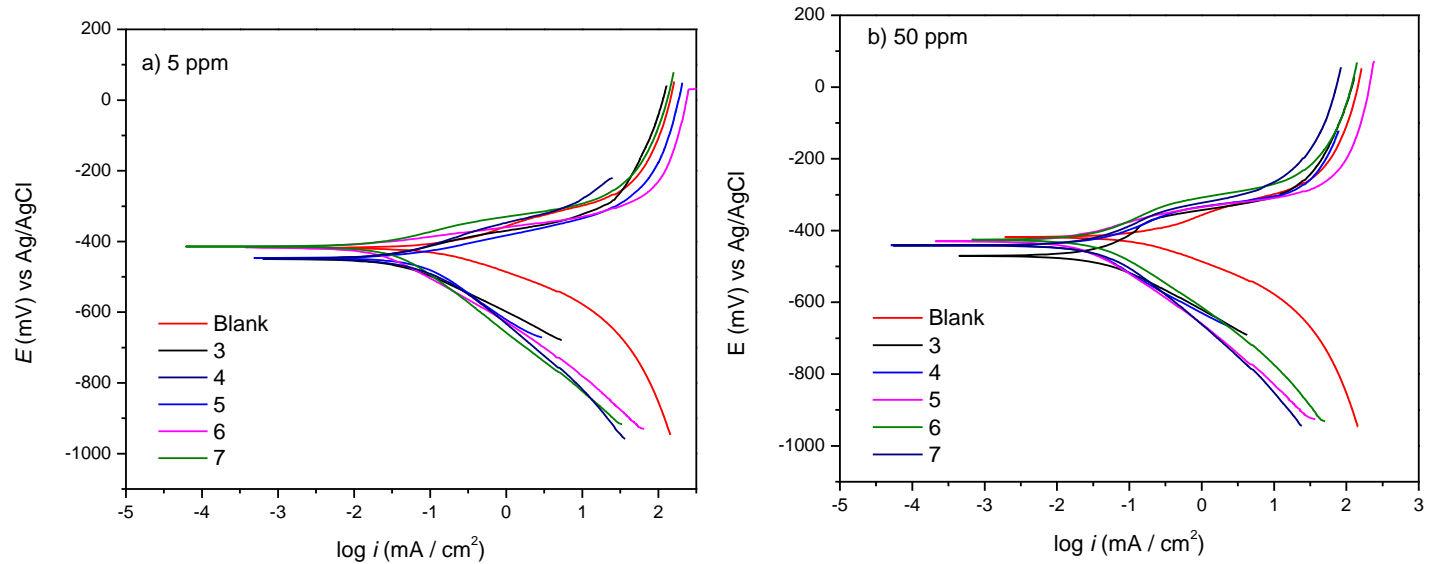


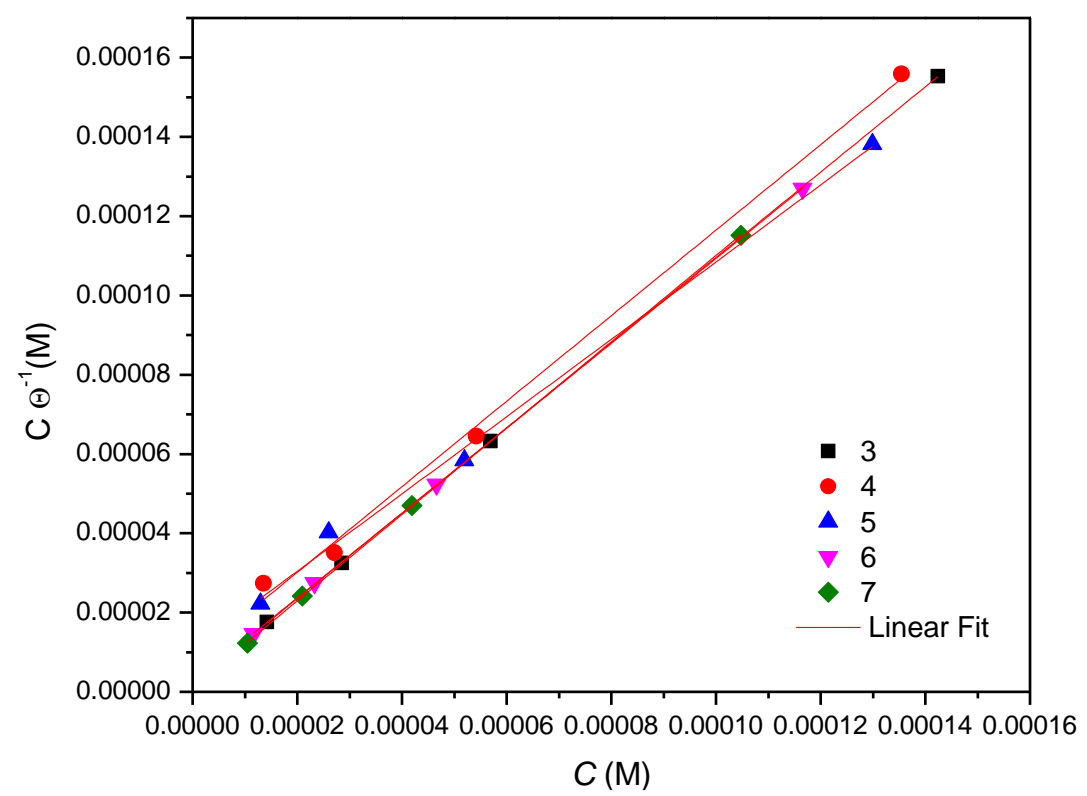



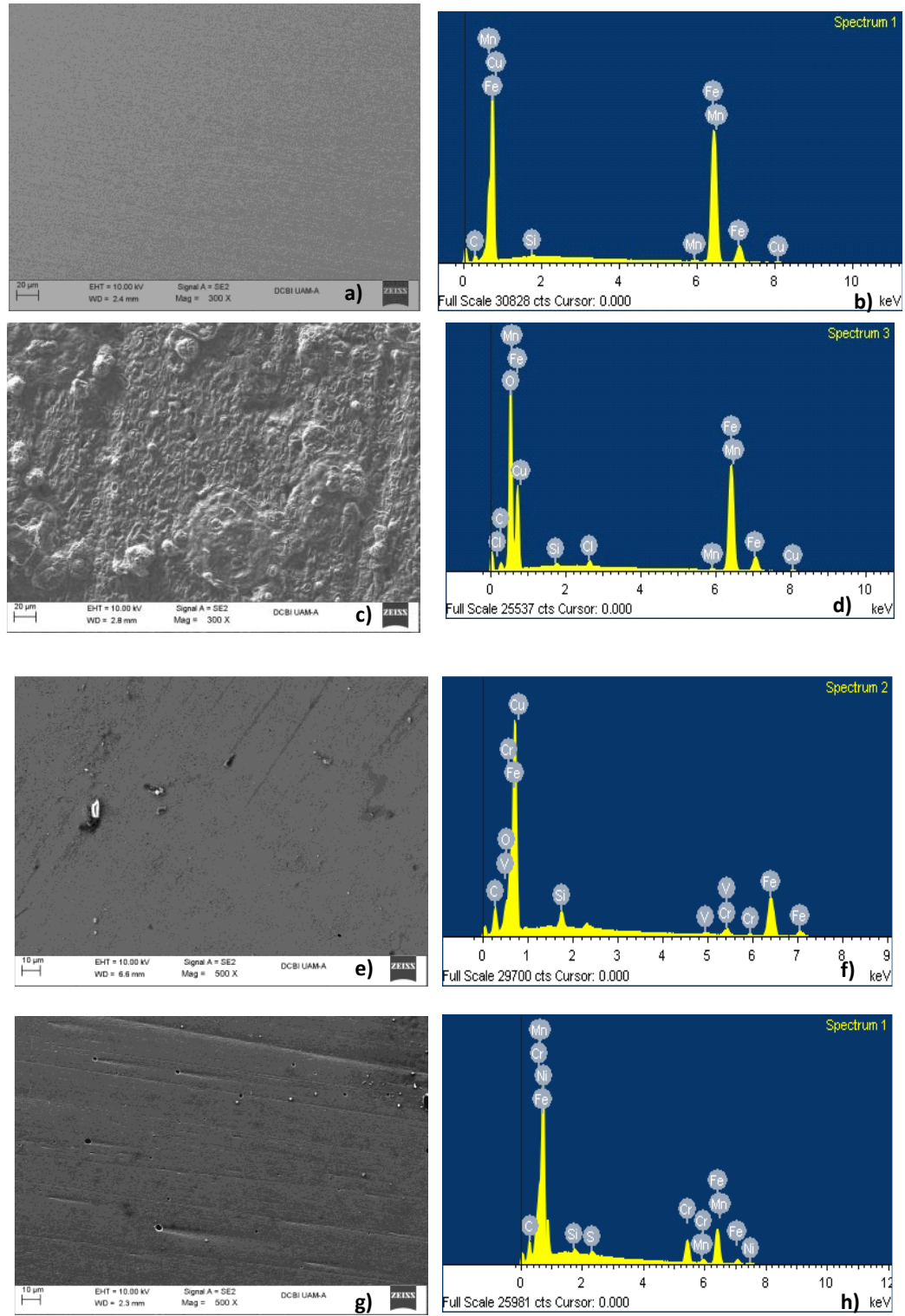